A JAPAN paper mentions a curious instance of Japanese thrift at Osaka. The paper made at the mill there is mostly manufactured from blue rags, and the water in which they are boiled has hitherto only poisoned the watercourses-; henceforth it is to be saved and the indigo extracted from it.

THE Manchester people have entered a fresh protest against centralisation by the publication of the Manchester Magazine, No. 2 of which lies before us, and devotes a fair proportion of its space to articles in science. Mr. L. H. Grindon writes on the art of distinguishing trees, and Mr. Angell on the Manchester Science Lectures. Prof. Osborne Reynolds writes on the Manchester Philosophical Society, and there are articles on Stargazing, the Phonograph, the Weather, \&c. Indeed the bulk of the magazine is scientific.

THE University Library at Strassburg has, according to the latest news, now reached the total of 470,000 volumes.

We have received a very favourable Report of the Auckland (N.Z.) Institute for I878-9. A considerable number of papers bearing on the natural history of New Zealand have been read during the session.

THE additions to the Zoological Society's Gardens during the past week include two Macaque Monkeys (Macacus cynomolgus) from India, presented respectively by $\mathrm{Mr}$. G. T. Close and Miss E. Catlin; a Garnett's Galago (Galago garnetti) from East Africa, presented by Mr. F. W. Barff; two African Civet Cats (Viverra civetta) from Africa, a Kinkajou (Cercoleptes caudivol. zuluss) from Demerara, presented by Lieut. M. B. Salmon, Indian Staff Corps; two Egyptian Gazelles (Gazella dorcas) from Egypt, presented by Commander J. Pratt, s.s. Fava; a Persian Gazelle (Gazella subgutturosa) from Persia, presented by Mr. C. H. Watts; three Hyacinthe Porphyrios (Porphyrio hyacinthinus) from West Africa, two Egyptian Kites (Miluus agyptizus) from Egypt, presented by Mr. A. Bells; a greater Sulphur-Crested Cockatoo (Cacatua galerita) from Australia, presented by $\mathrm{Mr}$. J. W. Taylor; a Slender-billed Cockatoo (Licmetis tenuirostris) from South Australia, presented by Mr. Geo. Wood; a Ring. necked Parrakeet (Palcornis torquatus) from India, presented by Mr. E. F. Carey; four Australian Wild Ducks (Anas super-ciliosa) from Australia, presented by Messrs. A. H. Jamrach and Charles Rice; two Pied Wagtails (Motacilla yarrelli), British Isles, presented by Mr. A. F. Wierner; a Common Badger (Meles taxus), British Isles; a Ceram Lory (Lorius garrulus) from Moluccas, an American Robin (Turdus migratorius) from North America, a West African Python (Python sebce) from West Africa, a Reticulated iPython (Python reticulatus) from Molucca, eleven Spotted Salamanders (Salanandra macalosa), European, deposited; a Beech Marten (Martes foina) from Russia, a Brazilian Tanager (Ramphocalus brasilius) from Brazil, twenty Spotted Salamanders (Salamandra maculosa), European, purchased; a Collared Fruit Bat (Cynonycteris collaris), two Jameson's Gulls (Larus jamesoni), bred in the Gardens.

\section{THE NATURAL HISTORY MUSEUM}

$T H E$ following memorial has been recently presented to the Earl of Beaconsfield :-

\section{To the Right Hon. the First Lord of the Treasury}

My Lord,-In accordance with a resolution adopted by the General Comanittee of the British Association for the Advancement of Science at their last meeting, the Council of the Association beg leave to call your attention to the following
circumstances.

I. In their fourth Report, presented to Parliament in 1874, the Royal Commission on Scientific Instruction and the Advance ment of Science, having fully considered the present state of the Natural History Departments in the British Museum, and taken evidence thereon from the country, state that they have come to the conclusion "that the objections to the present system of government of the British
Museum by a Board of Trustees as at present constituted, so far as relates to the Natural History Collections, are well founded, and that they have been unable to discover that the system is attended by any compensating advantages." They, therefore, recommend:"(I) That the occasion of the removal of these collections to the new buildings now being erected at South Kensington for their reception, be taken advantage of to effect a change in the governing authority and official administration of that division of the Museum. (2) That a director of the National Collections should be appointed by the Crown, and should have the entire administration of the establishment, under the control of a Minister of State, to whom he should be immediately responsible, and that the keepers of collections should be responsible to the director. That the appointments of keepers and other scientific officers should be made by the Minister, after communication with the Director and with the Board of Visitors (hereinafter referred to). And that the Director should prepare the estimates, to be submitted, after consultation with the Board of Visitors, for the approval of the Minister. (3) That the present superintendent be the first director. (4) That a Board of Visitors be constituted. That the Board be nominated in part by the Crown, in part by the Royal and certain other scientific Societies of the metropolis, and, in the first instance, in part also by the Board of Trustees; the members to be appointed for a limited period, but to be re-eligible; and that the Board of Visitors should make annual reports to the Minister, to be laid before Parliament, on the condition, management, and requirements of the Museum, and should be empowered to give him advice on any points affecting its administration."

2. Exactly the same view as to the desirability of effecting a change in the government of the Natural History Collections was taken in a memorial presented to the then Chancellor of the Exchequer in I 866, and signed by the Presidents and other wellknown members of the Royal, Linnean, and Zoological Societies, a copy of which is appended hereto.

3. Notwithstanding these expressions of opinion, in which nearly all the leading naturalists of the day fully concur, an Act was passed at the close of the last session of Parliament by which the Trustees of the British Museum have been anthorised to transfer the Natural History Collections into the new building at South Kensington, without making any change whatever in the present mode of their administration.

4. The Council of the British Association feel that it is not necessary for them to press upon the Government the arguments for the changes in the administration of the Natural History Collections which have been so amply stated by the Commis. sioners in the Report above-mentioned. The Council think it sufficient to call the attention of the Government to the fact that the provisions of the act are directly at variance with the recommendations of the Royal Commissioners.

5. As, however, a fresh application to Parliament will; be necessary in order to defray the expense of the removal of the Natural History Collections from their present situation to South Kensington, the Council of the British Association beg leave to point out to H.M. Government that the question of the administration of the Natural History Collections is one of the utmost importance as regards the future progress of Natural History in this country, and to urge upon them to take the opportunity which will thus present itself of effecting the alterations in the mode of administration of the Collections recommended by the Royal Commission. 'We have the honour to be, your Lordship's most obedient servants,

The Council of the British Association for the Advancement of Science

Signed, for the Council, W. Sportiswoode, President $\left.\begin{array}{l}\text { Douglas Galton, } \\ \text { P. L. Sclater, }\end{array}\right\}$ Secretaries

Copy of a Memorial Presented to the Right Hon, THE CHANCELLOR OF THE EXCHEQUER

To the Right Hon. the Chancellor of the Exchequer London, May 14, 1866 .

SIR, - It having been stated that the scientific men of the $\mathrm{Me}$ tropolis are, as a body, entirely opposed to the removal of the Natural History Collections from their present situation in the Natural History Collections from their present situation in the
British Museum, we, the undersigned Fellows of the Royal, Linnean, Geological, and Zoological Societies of London, beg leave to offer to you the following expression of our opinion upon the subject:- 
We are of opinion that it is of fundamental importance to the progress of the natural sciences in this country that the administration of the National Natural History Collections should be separated from that of the Library and Art Collections, and placed under one officer, who should be immediately responsible to one of the Queen's Ministers,

We regard the exact locality of the National Musenm of Natural History as a question of comparatively minor importance, provided that it be conveniently accessible and within the Metropolitan District.

GeORGE BeNTHAM, F.R.S., F.L.S., F.Z.S

WILLIAM B. CaRPENTER, M.D., F.R.S., F.L.S., F.G.S. W. S. DAllas, F.L.S.

Charles DarWin, F.R.S., F.L.S., F.Z.S.

F. DUCANE GODMaN, F.L.S., F.Z.S.

J. H. GURNEY, F.Z.S.

EDward Hamilton, M.D., F.L.S., F.Z.S

JOSEPH D. HOOKER, M.D., F.R.S., F.L.S., F.G.S.

Thomas H. HuXleY, F.R.S., V.P.Z.S., F.L.S., F.G.S.

JOHN KIRK, F.L.S., C.M.Z.S.

LILFORD, F.L.S., F.Z.S

ALFRED NewTON, M.A., F.L.S., F.Z.S.

W. KITCHEN PARKER, F.R.S., F.Z.S.

ANDREW RAMSAY, F.R.S., V.P.G.S.

Arthur Russell, M.P., F.R.G.S., F.Z.S.

Osbert Salvin, M.A., F.L.S., F.Z.S.

P. I. SCLATER, F.R.S., F.L.S., F.Z.S.

G. SCLATER-BOOTH, M.P., F.Z.S.

S. JAMES A. SAlTER, M.B., F.R.S., F.L.S., F.Z.S

W. H. SIMPSON, M.A., F.Z.S.

J. Emerson Tennent, F.R.S., F.Z.S.

Thomas Thomson, M.D., F.R.S., F.L.S.

H. B. Tristram, M.A., F.L.S.

WALDEN, F.Z.S., F.L.S.

ALFRED R. WALLACE, F.R.G.S., F.Z.S.

\section{SCIENTIFIC SERIALS}

THE Archives des Sciences physiques te naturelles (May, 1879) con review of Switzerland for the year 1878 , by M. Ernest Favre (continuation).-On the lake-dwellings of the Swiss lakes, by Dr. F. A. Forel. - On the rotatory power of isocholesterine, by E. Schulze. - On the existence in a gaseous state of nitrous anhydride and nitrous acid, by G. Lunge.

The Rivista Scientifico-Industriale (No. I0, 1879) contains the following articles:-On a new instrument to study microseismic phenomena, by Prof. Giovanni Mugna.-On the regress canals for the filling of ponds, by Francesco Cagnacci (3 plates).- - On the present state of Mount Vesuvius, by Prof. Semmola.-On the blue colours in manufacture of porcelain, by V. Joclet.

\section{SOCIETIES AND ACADEMIES LONDON}

Linnean Society, June 5.-Prof. Allman, F.R.S., president, in the chair-Attention was called to an article on Cinchona in India, by Mr. J. E. Howard. Calisaya Ledgeriana is shown to yield excellent results, as much as ro per cent. of quinine, and of excellent quality, being obtained.-Prof. Parker read a memoir on the structure and development of the skull in the Urodelous amphibia. Several forms are here worked out, the Spotted Salamander serving as a type. Some of the so-called skin bones appear early, other investing bones appear later, and the investing cartilaginous roof of the nose comes after the ear capsule cartilages. Some Urodela show a stapes absent in Ceratodus and Lepidosiren. The transformations of the Anoura are carried on in the plastic larva and young to a greater extent than in the Urodela. - A paper on the L.ichens collected during the English Polar Expedition of $i \delta 75-76$, by Prof. Fries, of Upsala, was communicated by Sir J. D. Hooker. In Dr. Hayes's Arctic journey lichens probably were not brought away from a more northerly position than $78^{\circ} \mathrm{N}$. lat., but Julius Payer, in the German Expedition, with certainty obtained specimens at Cape Fligely, $82^{\circ} 5^{\prime} \mathrm{N}$. lat. With the exception of these last, but three species of lichens hitherto have been published as found beyond $8 \mathbf{1}^{\circ} \mathrm{N}$. lat. Thus considerable interest is attached to those got under Capt. Sir G. Nares by Capt. Feilden, of the
Alert and Mr. Hart of the Discovery. As these vessels wintered in different quarters, the localities where the lichens were obtained correspondingly are more mumerous, thus adding to their value as indicative of vegetable life in the frozen regions. $\mathrm{Mr}$. Hart, got his at thirteen stations, Discovery Harbour, $8 \mathbf{1}^{\circ} 42^{\prime} \mathbf{N}$. lat., being the most northern; Capt. Feilden records twelve stations, Westward Ho Valley, $82^{\circ} 41^{\prime}$ N. lat. being the limit. But Lieut. Aldrich gathered Gyrophora cylindrica on the shore of the "Palæocrystic Sea," the northernmost spot trodden by man, viz., Cape Columbia, $83^{\circ} 6^{\prime} 30^{\prime \prime} \mathrm{N}$. lat. Prof. Fries notes that the so-called "fruticolous" and "foliaceous" lichen species are feebly represented, doubtless accounted for by the severe climate, but seemingly at variance with the presence of musk oxen; added to which the reindeer moss is absent. This anomalous circum. stance of the presence of large ruminants and deficiency of their usual lichen food, Capt. Feilden explains by stating that the musk ox in Grinnel Land does not feed on lichens, but on mosses and grasses. The same officer has also pointed out that the lichen growth curiously enough increased in size of species with increase of altitude. Prof. Fries concludes that, without the least credit being given to an open Polar sea (existing, no doubt, only in fancy), lichen vegetation may exist at the very Pole, if only land be there, and occasionally free from snow or ice. Among the series obtained in the Expedition, save a very few, all the forms of lichens of over 100 are already known. The abstract of a fourth contribution to the Mollusca of the Challenger Expedition, by the Rev. R. Boog Watson was read. This dealt with the Trochidæ and Turbinidæ. - The Secretary also read a communication on a remarkable new form of Helvella, this fungus being described by Mr. W. Phillips.-Mr. C. B. Clarke summarised a lengthened memoir by him, viz., a "A Review of the Ferns of North India." He showed that many of the localities given by Dr. Wallich, and doubtfully received by botanists were doubtless correct.-Mr. A. D. Michael was elected a Fellow of the Society.

Zoological Society, June I7.-Prof. W. H. Flower, F.R.S., president, in the chair-M Mr. Sclater exhibited a skin of Ara glauca, from Mr. Boucard's collection, obtained at Corrientes, and stated that having compared it with the Ara now in the Gardens, purchased in Jume, I860, and hitherto named $A$. glauca, he had come to the conclusion that the living bird belonged to the allied form Ara leari.-Prof. Flower called attention to the skull of the female sea-lion, which had lately died at the Southport Aquarium, and pointed ont that it belonged to Otaria gillespii, and not, as had been supposed, to Otaria stelleri. -Mr. C. G. Danford exhibited and made remarks on some remarkable antlers of deer, which he had obtained during his recent journey in Asia Minor,-Prof. Newton exhibited skins of some rare species of birds obtained by $\mathrm{Mr}$. Edward Newton, C.M.Z.S., in Jamaica. - Mr. F. D. Godman exhibited and made remarks on a drawing of the manatee by $\mathrm{Mr}$. Wolf, taken from the specimen lately living in the Westminster Aquarium.- Hass, Graf von Berlepsch, exhibited and made remarks on the skins of two varieties of the long-tailed titmouse (Mecistura caudata), which occurred near Cassel, in Germany, one of which appeared to be the sarne as the British form of this bird. -Dr. J. Murie read a paper on the manatee, containing the results of his examination of the specimen which was lately living in the Westminster Aquarium. The peculiar attitudes assumed by the animal in life, the great mobility of the upper lip, and the occasional use of the limbs in feeding were noted. As regards the anatomy, the chief points dwelt on were the shape of the brain and its suppressed convolutions. The vexed question of the number of the cervical nerves and their distribution was also discussed. - A communication was read from Mr. A. H. Garrod, on the brain and on other points in the structure of the adult male hippopotamus, which was presented to the Society by the late Viceroy of Egypt, in I85o, and which died in the Society's gardens in March, $1878 .-\mathrm{A}$ second communication from $\mathrm{Mr}$. Garrod contained a note on the mechanism of respiration, as well as of the retraction of the head and limbs in certain chelonia. -Dr. Gwyn Jeffreys communicated the second part of his work on the mollusca of the Lightning and Porcupine Expeditions, embracing the families from Anomizde to Arcidce. The number of species noticed was roo, of which 4 were new to science, and 15 were hitherto unfigured. Particulars were given of the geographical and geological distribution of all the species, and their synonymy was discussed. Some species of Leda and Malletia were Sicilian fossils of the pliocene formation, and had not been previous!y known as recent or living. These species 